\title{
PENGETAHUAN KOMUNITAS MOOI DALAM MENANGGULANGI PENYAKIT MALARIA DI KABUPATEN SORONG

\author{
Nanik Purwanti
}

\begin{abstract}
Abstrak
Perilaku kesehatan komunitas Mooi di Kabupaten Sorong untuk meningkatkan derajat kesehatannya sampai saat ini masih berdasarkan aspek sosial budaya setempat.

Penelitian ini bertujuan menjelaskan pengetahuan komunitas Mooi dalam menanggulangi penyakit malaria.Penelitian ini dilakukan di Kampung Maladofok Distrik Sayosa Kabupaten Sorong.Teknik pengumpulan data yang digunakan adalah observasi, wawancara, dan studi dokumen.Data dianalisis secara deskriptif kualitatif Hasil penelitian menunjukkan bahwa komunitas Mooi di Kabupaten Sorong sampai saat ini dalam menanggulangi penyakit malaria berdasarkan pengetahuan yang diperoleh secara turun temurun..
\end{abstract}

Kata Kunci : pengetahuan,komunitas Mooi,malaria

\section{PENDAHULUAN}

\section{A. Latar Belakang}

Penyakit malaria merupakan suatu fenomena kompleks yang berpengaruh negatif terhadap kehidupan suatu komunitas. Komunitas Mooi di kampung Mooi mendiami daerah yang berawa dan dikelilingi oleh hutan alam yang lebat dan belum terkontaminasi bahan kimia (insektisida) menjadi penyebab cepatnya perkembangbiakan nyamuk malaria di kampung Maladofok. Selain itu penyebaran penyakit malaria terdapat pula beberapa faktor lain yang mempengaruhi seperti ketidakseimbangan gizi, kesehatan lingkungan (pemanfaatan air bersih), pola permukiman (sanitasi lingkungan belum tertata baik sehingga saat hujan banyak genangan air yang potensial tempat perindukan nyamuk vektor malaria) dan kurangnya kesadaran akan kebersihan diri serta akses pelayanan kesehatan moderen

yang masih rendah, mengakibatkan anggota komunitas Mooi di kampung Maladofok mudah terjangkit penyakit malaria.

Adapun permasalahan-permasalahan tersebut,Peneliti tertarik untuk mengetahui bagaimana pengetahuan komunitas Mooi dapat menanggulangi penyakit malaria

\section{B. Rumusan masalah}

Dari latar belakang diatas maka masalah yang muncul adalah :

Bagaimana pengetahuan komunitas Mooi dalam menanggulangi penyakit malaria.

C. Tujuan dan Kegunaan Penelitian

1. Tujuan Penelitian

Penelitian ini bertujuan untuk:

Menjelaskan pengetahuan

komunitas Mooi dalam menanggulangi penyakit malaria.

2. Kegunaan Penelitian

Penelitian ini diharapkan dapat memberi manfaat secara akademis, penelitian ini dapat digunakan sebagai bahan bacaan dan wawasan khususnya dalam studi Antropologi Kesehatan, tentang pengetahuan penyakit malaria ditinjau dengan menggunakan pendekatan nilainilai budaya lokal.

\section{TINJAUAN PUSTAKA}

\section{A. Pengetahuan Kesehatan}

Pengetahuan tentang kesehatan mencakup apa yang diketahui oleh seseorang terhadap cara-cara memelihara kesehatan, seperti 
pengetahuan tentang penyakit menular, pengetahuan tentang faktor-faktor yang terkait atau mempengaruhi kesehatan, pengetahuan tentang fasilitas pelayanan kesehatan, dan pengetahuan untuk menghindari kecelakaan.(Becker www.wikipedia.org, 2010)

\section{A. Penyakit Malaria}

Penyakit malaria adalah suatu penyakit menular yang banyak diderita oleh penduduk di daerah tropis dan subtropis. Penyakit malaria merupakan penyakit yang sampai saat ini masih menjadi masalah utama kesehatan masyarakat di dunia dan Indonesia khususnya yang belum bisa ditangani secara tuntas. Penyakit ini disebabkan oleh infeksi parasit Plasmodium $s p$ yang disebarkan oleh nyamuk betina Anopheles $s p$ dan ditularkan dari orang sakit ke orang yang sehat melalui gigitan nyamuk tersebut sebagai vektor malaria. Wabah malaria bisa terjadi atau muncul karena berbagai pengaruh antara lain faktor lingkungan, faktor nyamuk sebagai vektor penyebab malaria dan faktor genetik dari parasit malaria itu sendiri (Arlan, 2004:2).

Bagan Kerangka Pikir

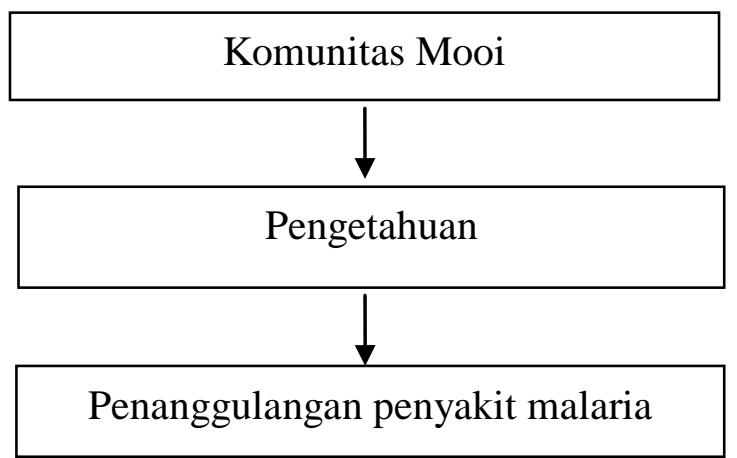

Kerangka operasional yang diuraikan dalam skema di atas menunjukkan bahwa komunitas Mooi di kampung Maladofok yang hidup secara subsisten mempunyai pengetahuan untuk menanggulangi penyakit malaria

\section{METODE PENELITIAN}

\section{A. Tipe Penelitian}

Sesuai dengan permasalahan dan tujuan yang hendak dicapai dalam penelitian ini, yakni deskripsi tentang pengetahuan komunitas Mooi dalam menanggulangi penyakit malaria, maka penelitian ini dirancang sebagai penelitian deskriptifkualitatif dengan pemaparan data secara deskriptif dan sistematis mengenai fakta-fakta di lokasi penelitian. Penulis mendiskripsikan, bagaimana pengetahuan dan kepercayaan komunitas dalam menanggulangi penyakit malaria. Data-data yang peneliti gunakan dtperoleh dari catatan lapangan (field note) berupa hasil-hasil wawancara di lapangan.

\section{B. Lokasi Dan Waktu Penelitian}

Penelitian ini dilaksanakan di komunitas Mooi kampung Maladofok, distrik Sayosa, kabupaten Sorong, selama bulan Januari sampai Maret 2017,dan laporan penulisannya selesai April 2017. Lokasi penelitian ini ditetapkan dengan pertimbangan bahwa meskipun komunitas Mooi di kampung Maladofok merupakan salah satu komunitas terpencil dengan cara hidupnya yang subsisten, namun mereka mampu menanggulangi penyakit malaria

\section{Infoman Penelitian}

Pemilihan informan dilakukan secara purposive sampling. Pemilihan informan secara purposive sampling dilakukan karena diantara komunitas yang ada di Papua, komunitas Mooi termasuk komunitas yang rentan terhadap penularan penyakit malaria karena cara hidup mereka yang subsisten tetapi mereka memiliki pengetahuan untuk menanggulangi penyakit malaria dengan menggunakan aspek-aspek sosialbudaya.

Penelitian ini terdiri dari seluruh unsur dan komponen yang terkait dengan pengetahuan komunitas dalam menanggulangi penyakit malaria.

Komuinitas Mooi dalam penanggulangan penyakit malaria di 
1) Tokoh-Tokoh masyarakat, termasuk di dalamnya para tokoh adat kampung Maladofok, 2)Anggota komunitas Mooi kampung Maladofok.

\section{Teknik Pengumpulan Data}

1. Pengamatan Tidak Berperanserta (Observation Non Participation)

Pengamatan langsung di lokasi penelitian dilakukan peneliti terhadap anggota komunitas Mooi dalam menanggulangi penyakit malaria, yaitu mengamati cara meracik ramuan tradisional sebagai obat malaria, ikut serta dalam mencari tanaman hutan yang dipercaya dapat menanggulangi penyakit malaria, mengamati tempat permukiman, lingkungan permukiman, pemanfaatan air bersih dan sarana prasarana kesehatan yang ada disekitar permukiman komunitas

\section{Wawancara Mendalam (Indept Interview)}

Bentuk wawancara yang dilakukan oleh peneliti diawali dengan membangun keakraban atau silaturrahim, komunikasi interpersonal dengan informan dan tokohtokoh masyarakat, dengan maksud memudahkan peneliti memperoleh data dari informan. Oleh karena itu, peneliti telah menyiapkan instrumen pertanyaan berstruktur.

\section{Dokumentasi}

Pengumpulan data dilakukan juga dengan kajian pustaka atau dokumen. Kajian pustaka atau dokumen penulis peroleh dari bahan bacaan atau referensi dan gambar atau foto yang penulis peroleh di lokasi penelitian. Analisis Data

Analisa yang digunakan dalam penelitian ini adalah analisis kualitatif deskriptif yaitu hasil wawancara, catatan lapangan, dokumendokumen dan lainnya. Kemudian mereduksi data dengan cara pengklasifikasian dan memanfaatkan data yang relevan. Data diklasifikasikan sesuai dengan fokus permasalahan. Data yang dikumpulkan dirunut untuk menjawab permasalahan yang diangkat dalam penelitian ini, yaitu pengobatan tradisional komunitas Mooi dalam kabupaten Sorong yaitu :

Sorong.

\section{GAMBARAN UMUM LOKASI PENELITIAN}

\section{A. Batas Administratif Kampung Maladofok \\ Secara administratif kampung} Maladofok memiliki batas-batas wilayah pemerintahan kampung sebagai berikut : a.Bagian timur : Distrik Sayosa

b.Bagian barat : Klomono c.Bagian utara : kali Klasafet d.Bagian selatan : Disfra (Hilir kali Klawilis)

\section{B. Keadaan Geografis}

Komunitas Mooi di kampung Maladofok merupakan komunitas terpencil di wilayah kabupaten Sorong dan berjarak $73 \mathrm{Km}^{2}$ dari kabupaten Sorong. Komunitas Mooi mendiami daerah berawa dan dikelilingi hutan alam yang lebat.

\section{HASIL DAN PEMBAHASAN}

\section{A. Pengetahuan Komunitas Mooi} Tentang Penyakit Malaria

1. Pengetahuan Komunitas Mooi Tentang Penyakit Malaria

Sampai saat ini, kehidupan komunitas Mooi di kampung Maladofok masih terasa suasana tradisionalisme. Keadaan tersebut berpengaruh dalam pemahaman konsep sehat-sakit didalam pemikiran komunitas.

Pengetahuan Komunitas Mooi Tentang Penyakit Malaria yang dimaksudkan dalam uraian sub bab ini adalah semua kegiatan atau aktivitas anggota komunitas Mooi dalam rangka memelihara kesehatan, seperti: a) Tindakan pencegahan terhadap penyakit malaria secara tradisional, b) Tindakan pengobatan terhadap penyakit malaria secara tradisional.

Sampai saat ini anggota 
penanggulangan penyakit malaria dikabupaten penyakit malaria, masih menggunakan ramuan tradisional yang dipercaya sebagai pencegahan dan pengobatan malaria. Ramuan tradisional tersebut, adalah jenis tanaman tertentu yang diperoleh dari hutan.

Ramuan tradisional yang digunakan komunitas Mooi di kampung Maladofok untuk mencegah penyakit malaria, sebagai berikut: minum air dari pohon air, minum rebusan air benalu, minum $g$

etah dari pohon merah dan makan daun papaya (gapailas wali) dan bunga pepaya (wali wifirik)

Cara alami yang digunakan oleh anggota komunitas untuk mengusir nyamuk malaria yaitu membuat pengasapan secara tradisional dari kulit kayu lawang atau kayu bakar.

Ramuan tradisional yang digunakan oleh Komunitas Mooi di Kampung Maladofok untuk mengobati penyakit malaria yaitu:

Akar dan kulit pohon tali merah (Gili); akar dan kulit pohon tali kuning (Udumbes), akar dan kulit pohon kayu susu (Ige), akar dan kulit pohon kayu putih (Mese) dan akar dan kulit pohon air. Berbagai macam akar dan kulit pohon tersebut, kemudian dipotong halus lalu dicuci bersih dan direbus sampai mendidih sampai airnya sisa kurang lebih antara 1 atau 2 gelas. Air ramuan tersebut diminum dalam keadaan hangat kepada pasien, supaya pasien mengeluarkan keringat. Menurut pengetahuan mereka kalau sudah berkeringat maka penyakit malarianya bisa cepat sembuh.

a) Daun pepaya (gapailas wali) serta bunga pepaya (wali wifirik).

b) Apabila badannya panas dahinya ditempel dengan daun cocor bebek.

c) Jahe merah (halea) digunakan sebagai penghangat tubuh saat menggigil kedinginan.

d) Dan daun gatal (semlas) digunakan sebagai obat sakit tulang pada saat sakit komunitas dalam menanggulangi

e) Kulit kayu panas digunakan sebagai obat malaria saat pasien merasa kepalanya pusing

\section{KESIMPULAN DAN SARAN}

\section{A. Kesimpulan}

Hasil analisis kualitatif deskriptif menunjukkan berdasarkan pengetahuan tentang penyakit malaria yang dimiliki secara turun-temurun, anggota komunitas dapat menanggulangi penyakit malaria.

\section{B.Saran}

1. Karena ramuan tradisional adalah merupakan kekayaan alam Bangsa Indonesia yang perlu dimanfaatkan secara optimal untuk meningkatkan kesehatan, selain obat farmasi. Diharapkan pemerintah kabupaten Sorong mengalokasikan dana APBD untuk membentuk Badan Penelitian dan Pengembangan Daerah supaya dapat melakukan penelitian melalui tes laboratorium tentang ramuan tradisional yang dipergunakan komunitas Mooi sebagai obat malaria. sehingga bermanfaat bagi masyarakat umum.

2. Diharapkan kepada masyarakat secara umum, untuk menjaga dan melestarikan hutan

\section{DAFTAR PUSTAKA}

Achmad Hidayat, Diki. 2006. Kumpulan Artikel /Jurnal Malaria

Arlan.Prabowo.2004.Malaria Mencegah \& Mengatasinya.Jakarta:Puspa Swara

Badan Pusat Statistik Kabupaten Sorong.2008.Kabupaten Sorong Dalam Angka 2008.Sorong:BPS Kabupaten Sorong

Budaya - Wikipedia bahasa Indonesia,ensiklopedia bebas, (Online), (Monzilla Firefox diakses 30 April 2010).

Foster/Anderson.1986.Antropologi Kesehatan.Jakarta:Universitas 


\section{Jurnal Noken 3(1) 31-36 2017}

malaria.

Koentjaraningrat. Metode Penelitian Masyarakat. 1977, Jakarta:Gramedia. Lumenta,Benyamin.1987.Penyakit Citra, Alam dan Budaya Tinjauan Fenomena Sosial.Yogyakarta:Yogyakarta.

Manfaat Air Kelapa.(Online), (Posted in Uncategorized I 21 Comments.18 September 2008 at 00:50 diakses 6 Juni 2010).

Mattulada.1997.Sketsa Pemikiran Tentang Kebudayaan \& Lingkungan Hidup.Makassar:Hasanudin University Press

Matsum,Iwan. tentang 2007. Determinan Perilaku,(Online), (www.depkominfo.go.id di akses 14 April 2010).

Numberi, Charles Drs. 2006.Bahan Ajar Sistem Sosial Budaya Lokal. Sorong: FISIP UNAMIN.

Notoatmodjo,Soekidjo.2007.Promosi

Kesehatan \& Ilmu Perilaku. Jakarta: Rineka Cipta

Pengertian Pengetahuan. (Online), (03/pengetahuan-dan-sikap-

tentangmalaria.html diakses 30 April 2010).

Poerwanto,Hari.2000.Kebudayaan dan Lingkungannya Dalam Perspektif Antropologi.Yogyakarta:Pustaka Pelajar

Pope,Geoffrey.1984.Antropologi Biologi.Jakarta:CV.Rajawali

Purwanti, Nanik, SS. 2001.Bahan Ajar Sistem Sosial Budaya Indonesia.

Rumbiak,Wilson.2009. Kajian Hukum Adat Suku Mooi Dalam Pemanfaatan Sumberdaya Alam Di Sorong.
Indonesia

Hasil Seminar Mahasiswa Pertanian Pasca Sarjana UNHAS.Tidak diterbitkan

Sugiyono. 2005. Memahami Penelitian Kualitatif. Bandung : Alfabeta

Sunanti Z. Soejoeti.Konsep Sehat, Sakit dan Penyakit dalam Konteks Sosial Budaya.Pusat Penelitian Ekologi Kesehatan, Badan Penelitian dan Pengembangan Kesehatan. Departemen Kesehatan RI Jakarta, (Online), (.http://skripsi-artikelmakalah.blogspot.com2010, diakses 15 April 2010)

Sunarto,Kamanto.1985. Pengantar Sosiologi Sebuah Bunga Rampai. Jakarta:Yayasan Obor Indonesia

Suwardi.Endraswara.2006.Metode,

Teori, Teknik Penelitian

Kebudayaan. Sleman Pustaka Widyatama

Yahoo. 2009. Ekologi Budaya. (Online) (http://www. yahoo search (henrinurcahyo@yahoo.com diakses 28 Desember 2008).

Zega,Adieli. Hubungan Kejadian Malaria Dengan Penghasilan, Pendidikan,Perilaku Pencegahan Dan Perilaku Pengobatan Masyarakat Di Kabupaten Kulon Progo, (Online), (www.kesehatanmasyarakat.co.cc. di akses 13 April 2010)

Sani,Yamin.2008.Bahan Ajar Mata Kuliah Antropologi Kesehatan.

Spradley,James.P.1997. Metode Etnografi.Yogyakarta:Tiara Wacana. 


\section{Jurnal Noken 3(1) 31-36 2017}

\section{Lampiran 1. Daftar nama informan}

\begin{tabular}{|c|l|c|c|c|c|l|}
\hline No & \multicolumn{1}{|c|}{ Nama } & $\begin{array}{c}\text { Jenis } \\
\text { Kelamin }\end{array}$ & Umur & Agama & Pendidikan & \multicolumn{1}{|c|}{ Pekerjaan } \\
\hline 1 & Afrida Klin & P & 25 & Kristen & SMP & Ibu Rumah Tangga \\
\hline 2 & Antonia Hu & P & 35 & Kristen & SD & Ibu Rumah Tangga \\
\hline 3 & $\begin{array}{l}\text { Barens } \\
\text { Galus }\end{array}$ & L & 42 & Kristen & SMP & Petani \\
\hline 4 & $\begin{array}{l}\text { Demo } \\
\text { Galus }\end{array}$ & L & 30 & Kristen & SMP & Petani \\
\hline 5 & Harun Knali & L & 55 & Kristen & SD & Petani \\
\hline 6 & $\begin{array}{l}\text { Jemmy } \\
\text { Papilaya }\end{array}$ & L & 55 & Kristen & S1 & Kepala Sekolah SD \\
\hline 7 & $\begin{array}{l}\text { Klemens } \\
\text { Galus }\end{array}$ & L & 45 & Kristen & SMA & Kepala Kampung \\
\hline 8 & Klin & L & 60 & Kristen & SMP & Guru Jemaat \\
\hline 9 & $\begin{array}{l}\text { K. Usily } \\
\text { L }\end{array}$ & 50 & Kristen & SMP & $\begin{array}{l}\text { Wakil Ketua LMA- } \\
\text { Malamoi Kab. Sorong }\end{array}$ \\
\hline 10 & Lis Saden & P & 38 & Kristen & SD & IbuRumahTangga \\
\hline 11 & Lukas Klin & L & 35 & Kristen & D3 & Mantri Polindes \\
\hline 12 & $\begin{array}{l}\text { Maria } \\
\text { Yempolo }\end{array}$ & P & 45 & Kristen & SD & Ibu Rumah Tangaa \\
\hline 13 & $\begin{array}{l}\text { Michael } \\
\text { Galus }\end{array}$ & L & 25 & Kristen & SMP & Petani \\
\hline 14 & $\begin{array}{l}\text { Moraid } \\
\text { Gisim }\end{array}$ & L & 40 & Kristen & SMP & Petani \\
\hline 15 & Obed Klin & L & 28 & Kristen & S1 & Calon Pendeta \\
\hline 16 & $\begin{array}{l}\text { Paulus } \\
\text { Yempolo }\end{array}$ & L & 62 & Kristen & SD & $\begin{array}{l}\text { Penyembuh } \\
\text { tradisional }\end{array}$ \\
\hline 17 & $\begin{array}{l}\text { Samuel Hu } \\
\text { Lamben }\end{array}$ & L & 61 & Kristen & SD & $\begin{array}{l}\text { Penyembuh } \\
\text { tradisional }\end{array}$ \\
\hline 18 & $\begin{array}{l}\text { Yuliance } \\
\text { Sesa }\end{array}$ & P & 35 & Kristen & D3 & Bidan Polindes \\
\hline 19 & $\begin{array}{l}\text { Yulius } \\
\text { Ginuni }\end{array}$ & L & 38 & Kristen & S1 & Kepala Sekolah SMP \\
\hline 20 & $\begin{array}{l}\text { Yunus } \\
\text { Yempolo }\end{array}$ & L & 45 & Kristen & SMP & $\begin{array}{l}\text { Penyembuh } \\
\text { tradisional }\end{array}$ \\
\hline
\end{tabular}

Sumber : Hasil olahan di lapangan, 2017 